\title{
Development of Module on Communicative Translation Material in Translation Subject
}

Titis Surgawi ${ }^{1}$, Hermanu Joebagio ${ }^{2}$, Djono $^{3}$

\begin{tabular}{l} 
ARTICLE INFO \\
\hline Article History: \\
Received 20.12.2018 \\
Received in revised form \\
05.03.2019 \\
Tarih girmek iç in buray1 \\
tiklatın. \\
Available online 01.07.2019
\end{tabular}

Available online 01.07.2019

\begin{abstract}
The lecture module is part of the lecture material which is systematic ally arranged based on the to pic of discussion and learning outcomes. This study aims to develop a translation module with communicative translation material in exercise questions and to know the effectiveness of using the module for the sixth semester students of the English Education Study Program at the Universitas PGRI Madiun (UNIPMA). Translation subject is given in the sixth semester to prepare students to master the theory of translation, source language and target language especially Indonesian and English as well as their fields of study. In addition, preparing students is proficient in translating. This module was developed using the ADDIE development model, namely 1) Analysis, 2) Design, 3) Development, 4) Implementation and 5) Evaluation. While the samples used in the effectiveness test were 30 class A students as the experimental class and 30 class B students as the control class. The results of product validation in the form of modules carried out by instructional materials experts and material experts obtained an average score of $92.88 \%$ so that the product is categorized as very good and suitable for use in the learning process. While the results of student responses to the module obtained an average score of $81.5 \%$ and categorized as good and appropriate to use in the learning process. Based on the acquisition of the average pre-test is 62 and post-test values is 71.33 , it can be concluded that student learning outcomes increase after using the learning module.
\end{abstract}

Keywords:

(C) IJERE. All rights resened

Translation, communicative translation, module

\section{INTRODUCTION}

Nida and Taber (1969) said that translation meant reproducing in the receptor language, the first natural equivalent of the source language message, first in terms of meaning and second in terms of style. While Larson (1984) argues that translation in translating text must consider vocabulary, grammatical structure, communication situation and cultural context of the source language to get a good translation. Then, Catford (1965) states that translation is the replacement of textual material in one language (SL) by equivalent textual material in another language (TL). The translated language is called the source language (Bsu) or the source language (SL), while the translation language is called the target language (Bsa) or the target language (TL). So, translation activities revolve around efforts to produce the meaning closest to the message contained in the source language into the recipient's language. In this case, the aspect of meaning must be a top priority, after that new aspects of style / language style. In translation there are three main principles, namely accurate, clear and natural (Larson, 1984). So that, a good translator is a translator who has competencies from both languages, both the source language and the target language and knowledge of the field of knowledge he translates and knows the right method for translating a text.

Observations conducted by researchers in the sixth semester of English Language Education Study Program UNIPMA showed that students' ability to translate simple texts in English and vocabulary mastery were still low, besides that students are still confused in translating a phrase, word or sentence contained in simple English text sentences. So that the problems encountered are student competency in translating English-language texts is not maximal, namely language competence and textual competence and lack of understanding of English and Indonesian. Based on Neubert (in Aris Wuryantoro, 2015), in general the competencies that must be possessed by an interpreter include language competence, textual competence, competence in the field of science and cultural competence. However, students are expected to have two competencies, namely language competence and textual competence. Language competence is a competency associated with mastering the source language and target language, for example English and Indonesian. While textual competencies in general are related to simple texts that will be translated, for example newspapers, magazines, advertisements, announcements, general instructions, journals and so on. In 
addition, the mastery of English and Indonesian languages is still low because in translating must be able to provide the right equivalent words from the source language into the target language because this can affect the message conveyed to the reader. Like Newmark's theory (1988) that communicative translation is translation that seeks to convey contextual meaning from the source language into the target language. So that, the researcher wants to provide a reference in the form of a print module for translation practice activities with communicative translation material.

According to Riyadhi, Djaiz \& Tapianto (2009), the module is a tool or means of learning that contains material, methods, limitations and ways of evaluating systematically and interestingly designed to achieve the expected competencies in accordance with the level of complexity. Wijaya (1987) explains that modules can be viewed as program packages arranged in the form of certain units for learning needs. The college module is part of the lecture material which is systematically arranged based on the topic of discussion and learning outcomes. The lecture module can consist of only one or more learning activities, depending on the learning structure planned. Modules are arranged according to the learning needs of a particular subject for the needs of a particular learning process, a competency or sub-competence in a single module (self contained), capable of self-learning or can be used to study independently (self-instructional), its use does not depend on other media (self alone), giving students the opportunity to practice and provide summaries, giving them the opportunity to carry out their own tests (self test) and accommodate student difficulties by providing follow -up and feedback.

\section{Situation of the Problem}

Based on this background of the study, the problems in this study is as follows: 1) how is the process of developing modules with communicative translation material? 2) is the translation module effective to be used in learning Translation subject?

\section{Aim of the Study}

The purpose of this study is to find out the process of developing modules with communicative translation material and the effectiveness of the translation module in learning Translation subject.

\section{METHOD}

The purpose of this study is to find out the process of developing modules with material communicative translation and the effectiveness of the translation module in learning Translation subject. The population of this research was 60 in the sixth semester students of the English Education Study Program at Universitas PGRI Madiun (UNIPMA).

The type of research used is research and development. According to Borg and Gall (1983) research and development is a process used to develop and validate educational products. This study follows a systematic step consisting of relevant research studies, developing products, testing products and revising the results obtained from these trials.

The learning model used refers to the ADDIE model namely analysis, design, development, implementation and evaluation (Januszew sky \& Molenda, 2008). ADDIE is a learning system design model that shows the basic stages of a learning system that is simple and easy to learn.

The first stage in this research is analysis. In the analysis phase, the activities carried out include analyzing the competencies that must be mastered by students; in real terms this module is realized by determining Competency Standards, Basic Competencies, and Learning Objectives, analyzing students' characteristic regarding the knowledge, attitudes, and skills possessed by students, and analyzing relevant material for achieving the desired competencies possessed by students.

The second stage is design. This stage is also known as the design term. In this stage a module / draft module is designed. The draft module is prepared based on the lesson plan of learning by paying attention to the competency standards to be achieved. The design is focused on three activities, namely the selection of material in accordance with the characteristics of students and the demands of competencies to be achieved, learning strategies, forms and methods of assessment and evaluation. 
The third stage is development. Development is the process of realizing design. During the development stage several activities were carried out such as: searching and gathering various relevant sources to enrich the material, making illustrations, charts, and graphics needed, typing, editing, and setting the module layout. Draft modules that have been designed will be validated by experts. This phase aims to identify shortcomings of the initial product that has been designed through two stages, namely expert validation and product testing before it is implemented. The aim is to identify deficiencies for products that have been designed. The determination of the eligibility criteria for the products produced is as follows:

Table 1. Product Eligibility Criteria

\begin{tabular}{ccc}
\hline Percentage & Qualifications & Value \\
\hline $\mathbf{9 0 \% - 1 0 0 \%}$ & Very good & $\mathrm{A}$ \\
\hline $\mathbf{7 5 \% - 8 9 \%}$ & Good & $\mathrm{B}$ \\
\hline $\mathbf{6 5 \% - 7 4 \%}$ & Enough & $\mathrm{C}$ \\
\hline $\mathbf{5 5 \% - 6 4 \%}$ & Less & $\mathrm{D}$ \\
\hline $\mathbf{0 - 5 4 \%}$ & Very less & $\mathrm{E}$ \\
\hline
\end{tabular}

The fourth stage is implementation. At this stage the results of the development are applied in learning to determine the effect on the quality of learning which includes effectiveness, attractiveness, and learning efficiency. Implementation is carried out on limitedgroups trials and wide groups to get input from students.

The fifth stage is evaluation. Evaluation is the process of seeing whether learning products made are successful, effective or not to be applied in learning. At this stage the effectiveness test is carried out using the SPSS application with the Paired Sample T-Test.

\section{RESULT, DISCUSSION, AND SUGGESTIONS}

The development of this module uses the ADDIE model, namely Analysis, Design, Development, Implementation and Evaluation.

\section{Analysis}

The first stage in this research is analysis. In the analysis phase, a preliminary study was carried out through observing Translation lectures in the classroom as well as obstacles in the learning process and interviewing with lecturers about the characteristics of students with regarding to knowledge, attitudes, and skills / possessed by students.

Based on the results of preliminary studies obtained information including student competence in translating English-language texts is not maximal, namely language competence and textual competence and lack of understanding of English and Indonesian. In the teaching and learning process in the Translation subject, it is illustrated that students are still confused in translating a phrase, word or sentence found in English texts. Most students expect that modules will be provided with the aim of being easier to learn and understand material especially those related to the practice of translating a simple text sentence with communicative translation material.

\section{Design}

At the design stage, the researcher prepares a draft module based on the lesson plan by paying attention to the competency standards to be achieved, determining what basic competencies will be contained in the translation module and determining the learning objectives that will be achieved after students take part in learning activities. Learning outcomes are adjusted to the basic competencies previously set.

\section{Development}


After the draft product is compiled, the next step is design validation carried out by instructional materials experts and material experts to provide an assessment of the product being developed. Some aspects assessed by teaching materials experts include presentation techniques, supporting presentation, learning presentation, content display and design. The results of instructional material expert assessment I obtained a score of $91.67 \%$ and instructional material expert II amounted to $90.67 \%$. Both of these scores can be categorized as good category. While material experts assess the suitability of the material with the Competency Standards and Basic Competencies, supporting learning materials and updating material. The results of the assessment of material experts I obtained a score of $95.83 \%$ and material experts II amounted to $93,75 \%$. Both of these scores are in the good category. The results of the assessment can be seen in the table below.

Table 2. Result of Experts Validation

\begin{tabular}{cccc}
\hline No. & Expert & Percentage & Category \\
\hline 1. & Instructional material expert I & $91,67 \%$ & Very good \\
\hline 2. & Instructional material expert II & $90,27 \%$ & Very good \\
\hline 3. & Material expert I & $95,83 \%$ & Very good \\
\hline 4. & Material expert II & $93,75 \%$ & Very good \\
\hline & Average & $92,88 \%$ & Very good \\
\hline
\end{tabular}

Based on table 2, the average score of the experts can be concluded that the initial product can be categorized as very good and feasible, continued at the stage of limited group trials and field group trials.

\section{Implementation}

After the product is validated by instructional material experts and material experts, the next step is product trial. The product trials were carried out in two stages, namely limited group trials and wide group trials. The aspects assessed in the user trial were the ease of understanding the material, the suitability of the material with daily life, reading clarity, clarity of the picture, clarity of learning instructions, attractiveness of colors used, ease of language and clarity of practice questions.

Table 3. Result of Product Trial

\begin{tabular}{cccc}
\hline No. & Respondense & Percentage & Category \\
\hline 1. & Limited group trials & $83 \%$ & Good \\
\hline 2. & Wide group trials & $80 \%$ & Good \\
\hline & Average & $81,5 \%$ & Good \\
\hline
\end{tabular}

Based on table 3, the average score of the assessment from a limited group trial and a wide group trial can be concluded that the initial product can be categorized as good and feasible to use in the learning process.

\section{Evaluation}

At this stage the effectiveness test will be carried out by involving class A as the experimental class and class $B$ as the control class. The experimental class is a class that uses products that are developed while the control class does not. In this stage it aims to determine whether the translation module with communicative translation material is more effective than the teaching materials used today and whether there are changes in learning outcomes. Before the effectiveness test is carried out, an equality test which consists of a normality test, a homogeneity test and an equality test is carried out first. This can be seen in the table below:

Table 4. Summary of Equality Test

\begin{tabular}{lll}
\hline Test & Sig. & Result \\
\hline
\end{tabular}



a. Normality
Control Class
0,062
Normal
Experiment Class
0,147
Normal
b. Homogenity
0,792
c. Equivalence
0,368
Homogenous
Equivalent

Based on the table above, it can be concluded that the experimental class and the control class have normal, homogeneous and equivalent initial data. Next to determine whether the translation module with material communicative translation is more effective in learning activities, the effectiveness test is carr ied out through the Independent Sample T-Test. The hypotheses used to make test decisions are as follows:

a. Hypothesis

H0: there is no difference in learning outcomes between the control class and the experimental class

H1: there are differences in learning outcomes between the control class and the experimental class

b. The testing using a two-sided test with a significance level of $\alpha=0,05$ or $5 \%$

c. Test decision:

$\mathrm{HO}$ is accepted if the probability value is significance or $\mathrm{sig}>0.05$. H0 is rejected if the probability value is significance or sig $<0.05$

The results of the effectiveness test through the Independent Sample T-Test can be seen in the table below:

Table 5. Result of Effectiveness Testsusing Independent Sample T-Test

\begin{tabular}{rlrll}
\hline & Types of test & Score & Sig. & Result \\
\hline a. & Normality & & & Normal \\
& Control Class & 62,00 & 0,145 & Normal \\
& Experiment Class & 71,33 & 0,136 & Homogenous \\
b. Homogenity Test & & 0,368 & H0 rejected dan H1 accepted \\
c. EffectivenessTest & & 0,000 & \\
\hline
\end{tabular}

Based on the table above, it can be concluded that the data in the experimental class and the control class are normally distributed and homogeneous. Based on the effectiveness test, the average value of the control class that has not used teaching materials in the learning process is 62.00 and the average value of the experimental class using the module is 71.33. Furthermore, the results of the Independent Sample T-Test were obtained by sig. (2-tailed) 0,000 <0,05 which can be concluded that $\mathrm{H} 0$ is rejected and $\mathrm{H} 1$ is accepted. It can be concluded that there is a significant difference between the average learning outcomes of the experimental class and the control class. Thus, the use of modules in translation lectures with communicative translation material is effectively used to improve student learning outcomes.

This is consistent with the research conducted by Bernadeta Ritaw ati (2017) which show s that multirepresentation based modules can improve the mathematical abilities of STKIP Melawi students in mathematics learning compared to those who do not use modules. In addition, a similar stu dy conducted by Achmad Irfan and Puput Wanarti (2014) shows that the development of electromagnetic field modules can improve students' high-level thinking abilities which are very important for building the scientific foundations of other electromagnetic and scientific fields studied at a later stage compared to slides power point from the lecturer. Research conducted by Habib Robbani (2018) states that modules are needed for teaching materials that can guide students to achieve learning goals in Maintenan ce and Repair Engineering Courses for Electronics Engineering Students of the Faculty of Engineering, Yogyakarta State University. Furthermore, the research conducted by Achmad Yusuf, Ardiana, Suharno and Sarwanto (2019) shows that science learning modules can be used for fifth grade elementary school students on the theme of animal and human motion organs and the theme of fresh air for health using learning models based on theory LCM is suitable for use. 
Based on the results of the research obtained, researchers suggest: 1) Translation of English-language texts conducted in the sixth semester of the current English Education Study Program is still low, so lecturers need to do the practice of translating regularly so that student competencies are better. 2) This communicative translation approach based translation module is included in both categories based on expert judgment and is suitable for use by students in translation learning. Before doing the exercises in the module, students should master the source language and target language well. 3) For further researchers, this translation module can be used as a reference and reference for similar research. So that it is expected that future research can provide more complete translation exercises.

\section{REFERENCES}

Borg, W. R., \& Gall, M. D. (1983). Educational research: An introduction. New York \& London: Longman.

Catford, J. (1965). A linguistic theory of translation. Oxford: Oxford University Press.

Irfan, A., \& Wanarti, P. (2014). Pengembangan Modul Pembelajaran Pada Mata Kuliah Medan Elektromagnetik I di Jurusan Teknik Elektro Universitas Negeri Surabaya. Jurnal Pendidikan Teknik Elektro , 3 (3), 543-551. http://jurnalmahasiswa.unesa.ac.id/index.php/jurnal-pendidikan-teknikelektro/article/view/9505

Januszewsky, A., \& Molenda, M. (2008). Educational technology: A definition with commentary. New York: Law rence Erlbaum Associates.

Larson, M. L. (1984). Meaning-based translation. Lanham: University Press of America, Inc.

Machali, R. (2009). Pedoman Bagi Penerjemah: Panduan Lengkap Bagi Anda Yang Ingin Menjadi Penerjemah Profesional. Bandung: Kaifa.

Nababan, M. R. (1999). Teori Menerjemah Bahasa Inggris. Yogyakarta: Pustaka Pelajar.

New mark, P. (1988). A textbook of translation. London: Prentice Hall.

Nida, E. A., \& Taber, C. R. (1969). The theory and practice of translation. Leiden: E. J. Brill.

Nugroho, A. Y. U., Hanatan, A., Suharno \& Sarwanto. (2018). Learning Module for elementary school students using learning model based on LCM theory. International Journal of Educational Research Review, 4 (1), 44-49.

Ritawati, B. (2017). Pengembangan Modul Berbasis Multipresensi Untuk Meningkatkan Kemampuan Representasi Matematis STKIP Melawi. Program Studi Pasca Sarjana Pendidikan Matematika Fakultas Keguruan dan Ilmu Pendidikan Universitas Tanjungpura Pontianak.

Riyadhi, N., Djaiz, M. \& Tapianto, T. (2009). Panduan Penyusunan Modul. Jakarta: Politeknik Negeri Media Kreatif.

Robbani, H. (2018). Pengembangan Modul Mata Kuliah Teknik Pemeliharaan Dan Reparasi Bagi Mahasiswa Teknik Elektronika Jurusan Pendidikan Teknik Elektronika dari Informatika FT UNY. Universitas Negeri Yogyakarta.

Wijaya, C. (1987). Upaya Pembaharuan dalam Pendidikan dan Pengajaran. Bandung: Remaja Rosda Karya.

Wuryantoro, A. (2015). Pernak-Pernik Penerjemahan. Madiun: Institut Press. 